\title{
Acquisition of the Labio-Dental Fricative /v/ in English L2 and Jamaican Creole: A Comparative Study
}

\author{
Ahmed Ibrahim Mousa ${ }^{1}$ \\ ${ }^{1}$ Department of European Languages and Literature, King Abdulaziz University, Jeddah, Saudi Arabia \\ Correspondence: Ahmed Ibrahim Mousa, Department of European Languages and Literature, King Abdulaziz \\ University, Jeddah, Saudi Arabia. E-mail: aimousa2004@yahoo.com
}

Received: September 30, 2013 Accepted: November 21, $2013 \quad$ Online Published: January 23, 2014

doi:10.5539/ijel.v4n1p60

URL: http://dx.doi.org/10.5539/ijel.v4n1p60

\begin{abstract}
This research attempts to investigate to what extent the claim that the strategies resorted to by second/foreign language learners are, more or less, the same as those used by speakers of pidgin/creole languages. To this end, the speech of two speakers of the well-known Broad Jamaican Creole is compared with the performance of Saudi learners of English, with respect to the pronunciation of the voiced labio-dental fricative /v/. It is found that the above claim is valid, in that before the fricative in question is acquired the speakers make use of another fricative as a transitory step. This behaviour is found to corroborate that of the child, which is recorded as external evidence that adds to existent literature of the logical problem of language learning. Furthermore, this strategy goes hand in hand with the norms of historical change, in that the substitute sounds are not marked. That is, although the pronunciation of [b] instead of $/ \mathrm{v} /$ is characteristic of the Broad Jamaican Creole, our Jamaican speakers prefer to use the bilabial fricative $[\beta]$, which is exactly used by the child. Likewise, our Arab learners make use of voiceless [f] for the voiced /v/ which is more marked.
\end{abstract}

Keywords: labio-dental fricative, Saudi learners, English as a second/foreign language, creole

\section{Introduction}

The ultimate goal of linguists is to decipher the mystery of the logical problem of language learning. That is, how a normal five-year-old human child acquires mother tongue (Brown, 1973). Another important aim of modern linguistic theory is to come up with language universals, the principles according to which all human beings speak a language (see Greenberg, 1966). Though it is important in the linguistic behaviour, the domain of phonology in second/foreign language learning and pidgin and creole languages has received little attention compared to the other aspects of language. Research has shown that child language, second/foreign language learning and pidgin and creole languages are more or less related in terms of processes. Many phenomena in these fields have been shown to be similar by Cook (1993), Bickerton (1995), Washabaugh (1977), Schumann (1978) and Holm (2000). Moreover, research on processes of pidginization and creolization has led to important advances in a number of areas of applied linguistics and theoretical linguistics (c.f. Holm, 2000). In this study, the strategies of language learning reported in Mousa (1994) are compared to the process of de/creolization (Bailey, 1966) of two speakers of Board Jamaican Creole. The similarities between the two creole speakers and Mousa's (1994) learners will be highlighted drawing on the assumption that "the dynamics by which pidgins and creoles come into being and the development of the L2 learner's interlanguage might be governed by the same factors" (Cook, 1993, p. 69). That is, in both situations the behaviour of those concerned is constrained by the principles of Universal Grammar, a genetically determined pre-disposition for language. Furthermore, we assume that second language learning, de/creolization and historical change are significantly linked, in such a way that accounting for the behaviour of the first two is never precise in the absence of historical facts.

\section{Literature Review}

As an interesting and promising domain of linguistic research, the comparison of non-native language acquisition with pidginization/creolization has attracted a significant number of linguists. This is so, because researchers have come to realize that, in order to understand the behaviour of early and late second/foreign language learning, an appreciation of the processes involved in pidginization/depidginization, creolization/decreolization is a key issue, McLaughlin (1987). For instance, Baxter et al. (1978), in their investigation of the Brazilian spoken dialect of Helvecia, observed a series of parallels with structures in early 
stages of L1 Portuguese acquisition.

In a comparison between the decreolization of the Guyanese Creole negation system and the acquisition of English negation by Spanish speakers, Schumann et al. (1978b) found that the overall movement along the linguistic continuum in the two operations involved a rule change from a basilect/basilange preverbal negation to the target English post-copula auxiliary negation. Furthermore, it was observed that the above rule change in the situations was accomplished by identical linguistic processes, the replacement of surface forms and the restructuring of underlying units. Likewise, in the depidginization of Hawaiian Pidgin English, as reported by Bickerton and Odo (1976), a continuum of development occurs which is similar to that produced in decreolization and second language acquisition.

Patrick-Andre (2006), in a recent study, has come to the conclusion that many of the features found in Haitian French-lexifier creoles do occur in L2 French and other interlanguages, as a result of L1 transfer and other acquisition processes. The investigation includes word-order within the noun phrase, pronominal clitics, the absence of copula, grammatical gender, and verb movement. The major claim of the model of creole genesis advocated in the study which he calls gradualist/second language acquisition, is that creole genesis does not involve any specific mental processes or strategies other than those attested in ordinary second language acquisition. In Lefebvre et al. (2003), a number of second language researchers and creolists engage in dialogues which focus on the processes characterizing various stages of L2 acquisition and creole genesis, such as relexification and transfer from L1 and their role in the initial state. The dialogues also cover morphological, phonological, semantic and syntactic properties of interlanguage grammar and creole grammars. Their findings lend support to the view that the same processes are found to shape the initial stages of the two situations.

\section{Current Study}

This study aims at investigating to what extent the linguistic processes exhibited in the creolization/decreolization parallel those manifested by Mousa's (1994) learners in particular and those of child language and second/foreign language in general. Furthermore, it is assumed that foreign/second language learning, de/creolization and historical change are significantly linked, in such a way that accounting for these learning situations is never precise without historical explanations. Thus, another aim of this study is to see to what extent the behaviour of the speakers of the Board Jamaican Creole and Mousa's learners exhibit facts of historical change. But before embarking on our investigation, introducing the Jamaican informants and the Saudi learners in Mousa's (1994) work is necessary.

\section{Jamaican Informants}

The informants are two speakers of what is called the Broad Jamaican Creole (Baily, 1973) of nearly the same age. The first one Mr. Mike (the barber henceforth), is from Hanover in the west of Jamaica. He migrated to Britain when he was 18 years old. Today he is 61 years old. He is a barber in Moss Side, Manchester, England. Most of his customers are West Indies, old and young. He uses the same language (Broad Jamaican Creole) at work, home and everywhere. He is always in touch with the West Indies people. He has little education. He left school before the age of 18 and his reading and writing are not perfect.

The second informant, Mr. Norman (the driver henceforth), is from St. Mary in the north of Jamaica. He migrated to Britain when he was 17. Today he is 59 years old. He worked in two factories in Manchester, as a dry cleaner, and as a carpet fitter before he became a taxi-driver, which is his present job. He also studied for a while in Jamaica and took a course in reading and writing in Manchester. This means that he dealt, and is still dealing with different people. Accordingly, his language is expected to be influenced more than that of the first informant.

\section{Data Collection}

Data gathering is based on three factors. Firstly, the author once lived with his informants for one year or so, which enabled him to observe a great deal of the properties of their speech. Secondly, he recorded their casual speech with their permission. Thirdly, in the process, he gave them separately a list of words and sentences to read, some of which are given below in table (1). In addition, examples will be citied in the analysis from the informants' casual speech when appropriate. It is important to mention that the Jamaican Creole transcriptions in this study are based on Cassidy (1961) and Cassidy and Le Page (1967), and the RP counterparts on Gimson (1980) and Roach (2000).

Transcribing and codifying data were done by the researcher himself, then checked by trained transcribers and a phonologist at the University of Bangor, North Wales. Data was coded manually to categorize the pronunciation of the fricative in question in the spontaneous speech and list reading of the subjects. For reference regarding 
Jamaican talk of the subjects, Cassidy (1961), Cassidy and Le Page (1967), Bailey (1966), and Holm (2000) were consulted. As for the Arabic speakers, the author referred to Basalamah (1990) and to his intuition as a native speaker of the dialect spoken by the Arab subjects.

The data displayed in (table 1) and (table 2) below contains information pertaining to the pronunciation of English voiced labio-dental fricative $/ \mathrm{v} /$.

Table 1. Words pronounced by the barber and the driver in casual speech

\begin{tabular}{|c|c|c|c|c|}
\hline Gloss & Driver & Barber & JC & $\mathbf{R P}$ \\
\hline seven & $/ \mathrm{se} \beta, \mathrm{m} /$ & $/ \mathrm{se} \beta, \mathrm{m} /$ & $/ \mathrm{se} \beta, \mathrm{m} /$ & /seven/ \\
\hline have & /hav/ & /hav/ & /hav/ & /hæv/ \\
\hline river & /rt $\beta \mathrm{a} /$ & /ri $\beta$ a/ & /riba/ & /rIva/ \\
\hline never & /nI $\beta \partial /$ & /nI $\beta \partial /$ & /nebə/ & /neva/ \\
\hline hoover & /hu:ßər/ & /hu:ßər/ & /hu:ßər/ & /hu:və/ \\
\hline vat & /væt/ & /væt/ & /væt/ & /væt/ \\
\hline
\end{tabular}

The following sentences and phrases are pronounced by the barber and the driver:

Barber:

Cab driver:

Barber:

Cab drivier:

Barber:

Cab driver:
/aI hav se $\beta \mathrm{m} /$

/aI hav se $\beta \mathrm{m} /$

/sIVIn $\theta 3:$ rtI/

/sIVIn $\theta 3:$ rtI/

/In mæi trlivizən/

/In mæI tIlIvizən/
I have seven.

Seven thirty.

In my television.

Table 2. The phonemic inventory of the barber and the driver

\begin{tabular}{|c|c|c|c|c|c|c|c|c|c|}
\hline & Bilabial & $\begin{array}{l}\text { labio- } \\
\text { dental }\end{array}$ & Dental & Alveolar & $\begin{array}{l}\text { Post } \\
\text { Alveolar }\end{array}$ & $\begin{array}{l}\text { Palato- } \\
\text { Alveolar }\end{array}$ & Palatal & Velar & Glottal \\
\hline Plosive & $\mathrm{p}, \mathrm{b}$ & & & $\mathrm{t}, \mathrm{d}$ & & & & $\mathrm{k}, \mathrm{g}$ & $?$ \\
\hline Affricate & & & & & $\operatorname{tr}, \mathrm{dr}$ & $t, d 3$ & & & \\
\hline Fricative & $\mathrm{b}$ & f, $v$ & $\theta, ð$ & $\mathrm{~s}, \mathrm{z}$ & & $\int, 3$ & & & $\mathrm{~h}$ \\
\hline Nasal & $\mathrm{m}$ & & & $\mathrm{n}$ & & & & $\mathrm{y}$ & \\
\hline Lateral & & & & $\mathrm{l}$ & & & & & \\
\hline $\begin{array}{l}\text { Frictionless } \\
\text { continuant } \\
\text { or glides }\end{array}$ & $\mathrm{w}$ & & & & $\mathrm{r}$ & & $\mathrm{J}$ & & \\
\hline
\end{tabular}

A glance at this inventory and the data in table 1 will make it clear that there are more differences between the English of our informants and that of RP speakers than their English and the one spoken by other speakers of the Broad Jamaican Creole in general, Cassidy (1961), Cassidy and Le page (1967), Wells (1973, 1982), among others. These differences will be explained in detail in the analysis.

\section{Mousa's (1994) Study}

The subjects of this study were 60 native speakers of Hejazi Urban Dialect (HUD), a variety of Arabic spoken in the urban areas of the Western province of Saudi Arabia, mainly Makkah, Madinah and Jeddah. They were divided into three groups, 20 in each. None of them had lived in an English-speaking country before the time of study. The first group consisted of pupils at the third year of their intermediate school. Their age ranged from 14 to 16 years. They had been studying English for three years, four hours a week. The second group was pupils of 
the third year at the secondary school. They were between 17 and 18 years of age. They had been exposed to English for six years at a frequency of four hours a week. The third group was university undergraduate students (third year level). They studied different subjects. They had been studying English for nine academic years. In this study, the major aspects of the Saudi learner's interphonology were dealt with. The study drew on the concept of transfer (Broselow, 1983, 1987) and markedness (Eckman, 1977) as two important factors that play major roles in shaping the learners' phonological acquisition. The analysis of the errors made by the learners was eclectic in that it was carried out in such a way that different theories of linear and non-linear phonology as well as theories of language acquisition both first and second, were employed. The study investigated the acquisition of English vowels, monophthongs and diphthongs, the acquisition of some problematic English consonants for Arabs, such as the voiceless bilabial stop /p/, the voiced labio-dental fricative $/ \mathrm{v} /$, the voiceless affricate $/ \mathrm{t} /$, the pronunciation of the approximant $/ \mathrm{r} /$ in general, and when it is preceded by the voiceless stops $/ \mathrm{p}, \mathrm{t}, \mathrm{k} /$, the pronunciation of consonant clusters and the acquisition of English stress. The analysis shows that the difference in parameter settings (Chomsky, 1981b; Archibald, 1990; Dresher \& Kay, 1990) between Arabic and English can easily explain why certain errors take place. A number of strategies such as sound substitution, consonant reduction, vowel epenthesis, glottal stop insertion, and the misplacement of stress, were employed in accordance with Arabic norms. The analysis also displayed that plenty of the strategies that were resorted to by the learners were similar to those found in child language and other L2 learning studies. The reader is reminded that the current research aims at investigating to what extent the linguistic processes exhibited in creolization and decreolization parallel those manifested by Arab learners of English in the above study in particular, and those of second/foreign language learning in general. But since the data in Mousa (1994) is enormous, care will be taken to cite only relevant information that serves the purpose of our investigation.

Table 3. Sample of Arab learners' pronunciation of /v/ in Mousa (1994)

\begin{tabular}{|c|c|}
\hline Gloss & Pronunciation \\
\hline solve & /so:lv/, /so:lf/ \\
\hline relative & /rilætif/ \\
\hline van & /fæn/ \\
\hline device & /difæis/ \\
\hline conversation & /kunfərse:fæn/ \\
\hline twelve & /təwilf/ \\
\hline alive & /2ælæif/ \\
\hline clever & /kəlifær/ \\
\hline volvo & /vulvu/, /fulfu/ \\
\hline wives & /wæifs/ \\
\hline vocal & /fukæl/ \\
\hline eleven & /ilifin/ \\
\hline
\end{tabular}

\section{Analysis and Discussion}

Our informants' pronunciation of the word "seven" reflects a marked trace of decreolization. That is, both informants repeatedly produced the word as $[\mathrm{se} \beta \mathrm{m}]$, with a bilabial fricative instead of labio-dental fricative. With this, they seem to have acted counter to our expectation. Thus, although the changing of $/ \mathrm{v} /$ to $/ \mathrm{b} /$ is a characteristic of Jamaican Creole, as in [neba] for "never" (Cassidy, 1961) and [lob] for "love" (Wells, 1973), the substitution of a voiced bilabial fricative $/ \beta /$ for the voiced labio-dental fricative is likely to happen among Bahamians, Bermudans and Vincentians (Wells, 1982). This pronunciation is formalized according to the following rule:

$$
\left(\begin{array}{l}
+ \text { labio-dental } \\
+ \text { fricative }
\end{array}\right) \rightarrow\left(\begin{array}{l}
+ \text { bilabial } \\
+ \text { fricative }
\end{array}\right) /\left(\begin{array}{l}
+ \text { nasal } \\
+ \text { bilabial }
\end{array}\right)
$$

According to the above rule, a labio-dental fricative becomes a bilabial fricative before a bilabial nasal. Then, 
where does this fricative come from?

Alleyne (1980) argues that the earliest English creoles did not have the fricative /v/. Actually, it is not found in some Atlantic creoles, including Jamaican Creole (Holm, 2000). Even in those creoles whose phonemic inventories display it, the sound is not originally theirs. For instance, although there is no contrast between orthographic $/ \mathrm{b} /$ and $/ \mathrm{v} /$ in American Spanish, as both are produced as $/ \mathrm{b} /$ with the bilabial fricative $[\beta]$ as an allophone, inter-vocalically, /b/ and /v/are two separate phonemes in Papiemento, though a Spanish based creole (Holm, ibid). Holm refers this to Dutch influence; hence [biha]- "travel", from Spanish "viajar" /bjaxar/ and [vibora]- "snake" from Spanish "vibora"/bibora/. Notice that whereas /v/ and /b/ are both pronounced as [b] in Spanish, they are pronounced as two separate phonemes in Papiemento, thanks to the above Dutch influence. Likewise, Saramaccan, an English based creole, has borrowed the fricative / $/$ from Portuguese and other languages, e.g., [vivo]- "alive" from Portuguese "vivo". The fricative $/ \mathrm{v} /$ is also absent from the phonemic inventories of many West African languages. In Bambara and Malinke which both lack the fricative in question, for instance, the voiced bilabial /b/ becomes its counterpart bilabial fricative $[\beta]$ inter-vocalically, as does the glide /w/ (Holm, 2000).

From what has gone so far, one has no choice but to postulate that our informants' use of the bilabial fricative in the pronunciation of "seven" must have been instigated by superstrate influence. That is, the above phonological rule of changing $/ \mathrm{b} /$ and $/ \mathrm{v} /$ to the bilabial fricative $[\beta]$ must have originated from Spanish. This assumption is justified along the following lines. English-based creoles come in two major groups, according to historical, geographical and linguistic factors: the Atlantic group, spoken in West Africa and the Caribbean area and the Pacific group. The Atlantic group consists mostly of plantation creoles which are structurally similar to the Atlantic creoles that are based on Portuguese, Spanish, Dutch and French (Holm, 2000, p. 91). Of these languages we are concerned with Spanish (regarding the existence of the voiced bilabial fricative in Jamaican Creole). The literature of pidgin and creole languages is replete with evidence of Spanish linguistic influence on the Caribbean area and on contemporary European languages there, including English. It is beyond the scope of this work to review this literature, but the reader is referred to Holm (2000) for details. According to Holm (ibid), the Spanish settlement in Jamaica began in 1509 and the English had to attack the Spaniards (who were there already) to rid them of the island before they colonized it. Thus, Spanish influence on the speech of the inhabitants is inevitable. Moreover, "contact between Spanish and creoles based on other languages was prolonged in several areas" (Holm, ibid, p. 126). In fact, people travel freely in the Caribbean, which makes contact among speakers of varied creoles effortless. At least, one cannot rule out the possibility that speakers of creoles based on other European languages than Spanish have been linguistically affected by the speakers of Spanish-based creoles such as the one spoken in Trinidad and Tobago, for instance.

As for the influence of West African languages on the speech of our informants, it has been argued that it is not clear whether their $[\beta]$ is typical of that of Bambara and Malinke, i.e., an allophone of /b/, inter-vocalically, or a fully fledged phoneme such as the one in Eve. In this West African language, bilabial fricatives contrast with

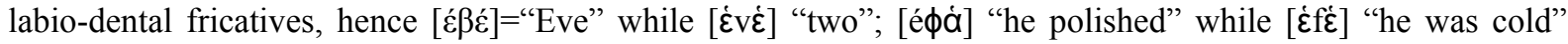
(Ladefoged, 1982, p. 144). Our informants seem to have produced the above fricative as an allophone and not as a fully-fledged phoneme. That is, their production is in accordance with the behaviour of the first two West African languages. Our arguments are as follows. First, there is no evidence in their speech that $[\beta]$ contrasts with [v]. Secondly, fricatives are marked sounds, therefore, stops are acquired first and used as substitutes for them (Jakobson, 1968), as a first transitional strategy. The second strategy towards the attempted fricative is to spirantize (Note 1) the stop, and this is an intermediate stage. Our informants are here now. The final stage is to produce the fricative in question. In fact, our informants did produce both $[\beta]$ and $[\mathrm{v}]$ in the pronunciation of "seven". This is interpreted as that the fricative in question is on the way of mastery and that they have moved along the continuum. In other words, they are between the mesolect and the acrolect stages (Note 2).

The gradual acquisition of the labio-dental fricative has also been reported in many varieties of pidgin and creole English. According to Hall (1966), /f/ and /v/ which are quite rare in the languages of the world were "replaced" in the initial stages by /p/ and /b/, respectively, e.g., Neo-Melanesian /pıngə(r)/- "finger" and /bılibım/- "believe him"; or Chinese Pidgin English /béli/- "very" (pp. 30-31). Likewise, Caribbean creolized English has exhibited remnants of /b/ for English /v/, e.g., /beks/ "to be annoyed", from English "vexed"; /nabel/ from English "navel" (Holm, ibid). The bilabial fricative $[\beta]$ is also used as a substitute for $/ \mathrm{v} /, / \mathrm{w} /$, and $/ \mathrm{b} /$ in the following varieties of creole English: Gullah, Bahamian, Liberian, Bay Islands of Islands of Honduras, and the speech of whites in coastal South Carolina (Holm, ibid).

Child language is another domain where one can seek more information in connection with the acquisition of fricative sounds. It is well known that children struggle in their attempt to acquire these sounds, and in most 
cases they are replaced by homorganic corresponding stops. At some stage, however, the child-knowing that these stops are not the ultimate target- exerts more effort to approximate the sound attempted. For instance, in the acquisition of the above fricative, the child has been reported to come up with a looser articulation by producing the semi-vowel [w], instead (Cruttenden, 1979; Crystal, 1987). Verma et al.'s (1992) children, the speakers of Punjabi-Urdu whose language lacks it, produced a labio-dental approximant $[\mathrm{U}]$ as a substitute for the fricative in question. The fricatives /f/ and $/ \mathrm{v} /$ failed to become established in the English of a Garo and English-speaking child. According to Burling (1978), these fricatives disappeared completely for sometime from the child's Garo and were replaced in English words by bilabial stops. Although the labio-dentals were fairly distinct at a later stage, they were more often bilabial fricatives. Use of a bilabial fricative in the place of a labio-dental fricative is also characteristic of defective children; in their speech $[\phi]$ is used as a substitute for /f/ (Winitz, 1969). The acquisition of English voiced labio-dental fricative $/ \mathrm{v} /$ by speakers of other languages is also marked with difficulty. In other words, speakers of varied L1s were reported to substitute it with the nearest sound in their phonemic inventories. Thus, Indians replace it with the labio-dental frictionless continuant $/ \mathrm{U} / \mathrm{G}$ Germans and Hungarians with the bilabial fricative $/ \beta /$ (Gimson, 1980) and many Arabs are said to use its voiceless counterpart /f/ (Mitchell \& El-Hassan, 1989). Before we elaborate on the use of $/ \mathrm{b} /$ and $/ \beta /$ as substitutes for $/ \mathrm{v} /$, we would like to discuss our learners' behaviour with respect to its acquisition. Our learners have problems both in identifying and producing this fricative. The beginners perceived it and produced it as $/ \mathrm{f} /$. The principle of setting up oppositional symmetries in the L1 sound pattern proposed by Jakobson (1968) would explain this error. That is, the voiced labio-dental fricative $/ \mathrm{v} /$ is missing from the Hejazi Arabic inventory which implies that this sound is marked (Note 3). The use of its counterpart, which is a legitimate sound in the learners' phonemic inventory, seems to be a case of interference from Arabic, based on Wode's (1980) assumption that only certain L1 elements are replaced by L2 elements. That is, elements that satisfy similarity requirement. The error made by the learners can also be ascribed to developmental factors. Stated differently, their response with the voiceless counterpart of the stimulus indicates that they are aware of the nature of the sound in question. In other words, they realize that the target sound is a labio-dental fricative with the feature [+continuant] as a characteristic. Another demonstration of the developmental aspect of our learners' performance regarding the acquisition of this phoneme is the variation of $/ \mathrm{v} /$ with [f] which indicates, perhaps, that the voiced-voiceless contrast is developing (Albright \& Albright, 1958; Ferguson \& Farwell, 1975). Therefore, we assume that more exposure to the target sound will enable them to produce it more authentically. Hecht \& Mulford (1987) argue that, in second language learning, if the developmental hypothesis best accounts for L2 acquisition of phonology, then learners should have the most difficulty producing those fricatives known to be acquired last by the L1 learners. Indeed, /f/ is mastered at the age of three, and $/ \mathrm{v} /$ at six (Winitz, 1969). On the other hand, a number of advanced learners faced almost no difficulty perceiving and producing the fricative under investigation. Their better performance may be ascribed to either one of the two following factors or both. It could be due to more exposure to this fricative through formal instructions or contact with native speakers of English, or it could be the consequence of borrowing. A number of words in the Arabic lexicon which have been borrowed form English and which contain the voiced fricative $/ \mathrm{v} /$ are still pronounced with the same fricative by many Arabs, although some would pronounce them with [f]. For instance, "television", "van", "villa", or the equivalent of "he got me on my nerve" would be produced as [tılıvızjo:n], [væn], [villo], and [narvoznı], respectively. There are so many cases in which borrowing is taken to be of great support in mastery of foreign language aspects. For instance, Kazakh, a Turkic language spoken in Central Asia does not have the voiceless labio-dental fricative in its phonemic inventory, as there are no native Kazakh words bearing this sound. With loan Russian words containing this phoneme, however, most Kazakh speakers tend to use it. Consider the following examples:

$$
\begin{aligned}
& \text { "flot"-fleet, } \\
& \text { "filosof"-philosopher, } \\
& \text { "fizik"-physics, }
\end{aligned}
$$

from Russian "flot";

from Russian "filosof"; and

from Russian "fizika” (Arlotto, 1972).

Thus, our advanced learners' better performance in learning this fricative seems to have taken place pending on more exposure to the sound, or as a result of borrowing, or both.

But the use of the bilabial fricative $[\beta]$ as a transitory realization of $/ v /$ is worth considering. We have seen that this fricative is used in many Caribbean creoles, some West African languages, by Germans, by Hungarians, by the child (Moskowitz, 1970) and by our Jamaican informants, and almost all are targeting the voiced labio-dental fricative $/ \mathrm{v} /$. There seems to be a clear pattern in the way these speakers behave when it comes to the learning of this fricative. In other words, its learning goes through three stages: it is realized as the stop [b] in stage 1, as the voiced bilabial fricative $[\beta]$ in stage 2 , and as the target fricative $/ \mathrm{v} /$ in stage 3 . Accordingly, one would like to question if these stages have anything to do with the set of developments of Latin intervocalic $/ \mathrm{b} /$ in the Modern 
Romance Dialects. Latin intervocalic $/ \mathrm{b} /$ is realized as $[\mathrm{v}]$ in Italian and French, but as $[\beta]$ in Spanish, hence Latin "habēre" "have", Italian "avere", French "avoir", and Spanish "haber" (pronounced with [ß]) (Lass, 1984). One can see the resemblance between the stages of the acquisition of the fricative in question and the development of Latin intervocalic $/ \mathrm{b} /$.

Finally, the history of the language shows that English voiced labio-dental fricative /v/ derives from Old English /f/ which was realized as /v/ intervocalically, e.g., "love", "wolves", "devil", etc. Word- initially and finally, probably the allophone [f] was used. With the increasing number of loan words from French with initial [v], e.g., "vine", "village", "veal", etc., these allophones were recognized as distinct phonemes (Gimson, 1980; Bynon, 1977). According to Winitz (1960), as mentioned earlier, the voiceless labio-dental /f/ is acquired first in child language at the age of three, but the acquisition of the voiced counterpart lags until seven, indicating its complexity. In second/foreign language learning, the tendency to devoice final voiced stops by German speakers is retained when pronouncing voiced English fricatives word finally (Allan James, personal contact). Moskowitz (1970) reports that her child Erica does the same with respect to the fricative in question. Also, though our beginning learners are aware of the fact that the target sound is [+continuant], in that their substitute is actually characterized as such (i.e., [f]), they failed to come up with the fricative in question, because of what is known as the "inter-lingual identification" (Odlin, 1989). That is, the learners seem to have established an equivalence relation between their native $/ \mathrm{f} /$ and the target $/ \mathrm{v} /$. Therefore, they did not make the required effort in its production.

In the situations where the speakers of creole come in contact with the speakers of the superstrate language, i.e., the lexical donor language, there has been a historical tendency for the creole to shed its most salient features which set it apart from the donor language which is usually European. This process is known as "decreolization". It results in "a continuum of varieties from those farthest from the superstrate (the basilect) to those closest (the acrolect), with (mesolectal or intermediate varieties between them" (Holm, 2000, p. 10). The extent to which an individual speaker is decreolized will, of course, be determined by the amount of the encounter he/she has with acrolectal speakers. That is, an individual's linguistic development is socially determined (Schumann and Stauble, 1983). For instance, Rickford (1999) reports that Mr. Seymour, a cane-cutter who can speak a basilectal/lower mesolectal variety of creole, rarely uses this in the interview situations. As a "big-time" contractor, with plenty of occupational and other contacts outside the village where he lives, he generally uses an upper mesolectal/acrolectal variety with his interviewees. Mr. Seymour's younger daughter Katherine, who goes to school, however, speaks what Rickford (ibid) calls an almost flawless acrolet, and amazingly enough, seems incapable of speaking the basilectal and lower mesolectal realizations of creole.

According to Le Page and Tabouret Keller (1985), commenting on DGL, a speaker of Belizean English-based creole who left the creole environment, she was much on her guard linguistically than she had been earlier when she had been one of the "broader creole speakers". They add, however, that other Belizeans who did not have the same chance and therefore had to remain as agricultural labourers or as factory workers exhibited less linguistic change. From the above situation Rickford (1999) concludes that, urged by the awareness of the so called social prestige and stigma associated with the varieties of Belizean speech (hence a psychological motive), those speakers did their utmost to increase their capability in using lects closer to the standard English end of the continuum.

In the following lines, an attempt is made to report to what extent our Jamaican informant's pronunciation of the fricative in question has changed, as a result of their immigration to Britain. Their performance will be compared with that of our Arab learners of English, to see to what extent the linguistic processes exhibited in creolization/decreolization parallel those of second/foreign language learning.

It is quite clear that our informants have made dramatic progress towards RP. They do not produce this fricative as [b], which is a characteristic of Jamaican creole; instead, they produce the target sound or something nearest to it as a transitory realization. That is, they produce $/ \mathrm{v} /$ and the bilabial fricative $[\beta]$. Both informants produce $/ \mathrm{v} /$ in "very", "hoover", "have" and so on. They might have mastered it in Britain as a result of networks. One can also argue that the barber's use of $[\beta]$ is not a sign of decreolization, but rather an influence of those Caribbean customers whose creoles have it in their phonemic inventories. On the other hand, the cab driver's use of $[\beta]$ may be taken as a step towards RP, for the following reason. It could be the influence of educated speakers. For instance, Gimson (1980) argues that in rapid, familiar speech, where easy intelligibility rather than articulatory presicion is the aim, the closure of plosives is often so weak that the corresponding fricative sound, without a preceding stop, is produced, especially in weakly accented intervocalic positions. The following examples have been noted among educated speakers: imported [Impo:sId], invaded [InveIzId], baker [beIxə], dagger [dæ\ə] (this latter, on the stage, in the Macbeth "dagger" soliloquy), and even pepper [peфə], rubber 
$[\mathrm{r} \wedge \beta$ ə] (p. 160). Again, the link between stops and fricatives, in terms of articulation, is highlighted in the above quotation. That is, it seems that in the articulation of a stop the articulation of a fricative is possible, as a transitory strategy, and that in the articulation of a fricative the articulation of a stop is possible as a transitory strategy. Thus, our cab driver might have heard educated RP speakers producing English words, including "seven", in the above manner, but although [sébm] is a possible pronunciation (Lehmann, 1962, p. 167), he opted for $[\mathrm{sé} \beta \mathrm{m}]$. That is, due to the awareness of social prestige and stigma associated with Jamaican pronunciation of the word (i.e., [sébm]), he chose to pronounce it in accordance with the way it is said by educated British speakers (i.e., as either [séßm] or [sévm]). It is quite interesting that the same behaviour is interpreted differently.Thus, whereas use of the bilabial fricative [ $\beta]$ is taken to be basilectal in the case of the barber, it may suggest the mesolectal or acrolectal feature of the cab driver's speech. Stated differently, once the barber socializes with speakers of Caribbean creoles whose varieties posses this sound as a genuine member of their phonemic inventories, and who have almost no encounters with speakers of standard English, one cannot ascribe the barber's use of $[\beta]$ to decreolization. The opposite is true for the other informant, whose daily encounters with speakers of standard English would definitely motivate linguistic change.

In the case of our learners, we take it that the beginning learners and the advanced ones are all moving towards the target fricative. The former, however, are expected to lag behind for sometime due to lack of contact with speakers of standard English or due to the need for more formal instructions, the sources which are expected to raise their consciousness regarding the difference between their $/ \mathrm{f} /$ and the target $/ \mathrm{v} /$. On the other hand, having been exposed to more formal instructions and having established contact with speakers of standard varieties of English, perhaps, the advanced learners face less difficulties, both recognizing and producing the novel sound. Notice that our learners did not have to go through the transitory stage at which the bilabial fricative $[\beta]$ is used. This is simply because the above case of transfer seems to have given them what James (1989) calls a "head start". But one can also argue that the substitute used by the speakers in the three domains (i.e., L1, L2, and pidgin / creole languages) is justifiable in that they abide by norms of historical change. In other words, it has always been reported that changes take place from marked to less marked. For instance, use of the bilabial fricative $[\beta]$ instead of $/ \mathrm{v} /$ by speakers of Jamaican Creole though the stop $/ \mathrm{b} /$ could be used seems to indicate preference for a less marked sound. As for Arab learners and the child, pronouncing the sound as voiceless labiodental [f] is another proof in support of preference for using less marked articulation (c.f., Arlotto, 1972; Lass, 1984; Bynon, 1977; Gimson, 1980, to stand at the development of labio-dental fricatives).

\section{Conclusion}

To conclude, the claim that the strategies resorted to by second/foreign language learners are, more or less, the same as those used by speakers of pidgin/creole languages is investigated. To this end, the speech of two speakers of the well-known Broad Jamaican Creole is compared with the performance of Saudi learners of English, with respect to the pronunciation of the voiced labio-dental fricative $/ \mathrm{v} /$. It is found that the above claim is valid, in that before the fricative in question is acquired the speakers make use of another fricative as a transitory step. This behaviour is found to corroborate that of the child, which is recorded as external evidence that adds to existent literature of the logical problem of language learning. Furthermore, this strategy goes hand in hand with the norms of historical change, in that the substitute sounds are not marked. That is, although the pronunciation of $[\mathrm{b}]$ instead of $/ \mathrm{v} /$ is characteristic of the Broad Jamaican Creole, our Jamaican speakers prefer to use the bilabial fricative $[\beta]$, which is exactly used by the child. Likewise, our Arab learners make use of voiceless [f] for the voiced $/ \mathrm{v} /$ which is more marked. This work can have effects on studies of second language acquisition and learning and also on curriculum design.

\section{Acknowledgements}

This research was made possible through a grant from the Deanship of Scientific Research, King Abdulaziz University, Jeddah, Saudi Arabia (Project No 427/452). The author wishes to acknowledge that.

\section{References}

Albright, R., \& Albright, J. (1958). Application of Descriptive Lingusitics to Child Language. Journal of Speech and Hearing Research, 1, 257-261.

Alleyene, M. C. (1980). Acculturation and the Cultural Matrix of Creolization. In D. Hymes (Ed.), Pidginization and Creolization of Languages. Cambridge: CUP.

Archibald, J. (1990). The Acquisition of English Metrical Parameters by Polish Speakers: Quantity-Sensitivity and Adult Access to OG. Paper presented at the Boston University Conference on Language Development.

Arlotto, A. (1972). Introduction to Historical Linguistics. Boston: Houghton Mifflin. 
Bailey, B. (1966). Jamaican Creole Syntax. Cambridge: CUP.

Basalamah, M. S. (1990). A study of Certain Aspects of the Superasegmentals of Arabic and Their Influence on the English Pronunciation of Arab Teachers of English in the Western Zone of Saudi Arabia (Unpublished doctoral dissertation). University College London, London.

Baxter, A., Lacchesi, D., \& Guimaraes, M. (1997). Gender Agreement as a Decreolizing Feature of an Afro-Brazilian Dialect. Journal of Pidgin and Creole Languages, 12, 1-57. http://dx.doi.org/10.1075/jpcl.12.1.02bax

Bickerton, D. (1995). Creoles and the Bankruptcy of Current Acquisition Theory. In W. Herman (Ed.), Creole Languages and Language Acquisition. Berlin: Mouton de Grunter.

Bickerton, D., \& Odo, C. (1976). General Phonology and Pidgin Syntax. Vol. 1 of Final Report on National Science Foundation Grant No. Gs-39748.

Broselow, E. (1983 \& 1987). Non-Obvious Transfer: On Predicting Epenthesis Errors. In S. Gass, \& G. Selinker (Eds.), Language Transfer in Language Learning (pp. 269-280). Rowley: Newbury House.

Brown, R. (1973). A First Language: The Early Stages. Cambridge, Mass: Harvard University Press. http://dx.doi.org/10.4159/harvard.9780674732469

Burling, R. (1978). Language Development of a Garo- and English-Speaking Child. Word, 15, 45-68.

Bynon, T. (1977). Historical Linguistics. Cambridge: CUP. http://dx.doi.org/10.1017/CBO9781139165709

Cassidy, F. G. (1961). Jamaican Talk. London: Macmillan.

Cassidy, F. G., \& Le Page, R. B. (1967). Dictionary of Jamaican English. London and New York: CUP.

Chomsky, N. (1981b). Principles and Parameters in Syntactic Theory. In N. Hornstein, \& D. Lightfoot (Eds.), Explanation in Linguistics (pp. 32-75). London: Longman.

Cook, V. (1993). Linguistics and Second Language Acquisition. Basingstoke: Macmillan.

Cruttenden, A. (1979). Language in Infancy and Childhood. Manchester: Manchester University Press.

Crystal, D. (1987). The Cambridge Encyclopedia of Language. Cambridge: CUP.

Dresher, B., \& Kaye, J. (1990). A Computational Learning Model for Metrical Phonology. Cognition, 34, 137-195. http://dx.doi.org/10.1016/0010-0277(90)90042-I

Eckman, F. (1977). Markedness and the Constrastive Analysis Hypothesis. Language Learning, 27, 315-330. http://dx.doi.org/10.1111/j.1467-1770.1977.tb00124.x

Ferguson, C., \& Farwell, C. (1975). Words and Sounds in Early Language Acquisition. Language, 51, 419-39. http://dx.doi.org/10.2307/412864

Gimson, A. C. (1980). An Introduction to the Pronunciation of English. London: Edward Arnold.

Greenberg, J. (1966). Universals of Language. Cambridge, Mass: MIT Press.

Hall, R. (1966). Pidgin and Creole Languages. Ithaca: Cornell University Press.

Hecht, B., \& Mulford, R. (1987). The Acquisition of a Second Language Phonology: Interaction of Transfer and Developmental Factors. In G. Ioup, \& S. Weinberger (Eds.), Interlanguage Phonology: The Acquisition of a Second Language Sound System. Rowley: Newbury House.

Holm, J. (2000). An Introduction to Pidgins and Creoles. Cambridge: CUP. http://dx.doi.org/10.1017/CBO9781139164153

Hyman, L. (1975). Phonology: Theory and Analysis. New York: Holt, Rinehart and Winston, Inc.

Jakobson, R. (1968). Child Language, Aphasia and Phonological Universals. The Hague: Mouton.

James, A. (1989). Linguistic Theory and Second Language Phonological Learning: A Perspective and Some Proposals. Applied Linguistics, 10, 367-381. http://dx.doi.org/10.1093/applin/10.4.367

Ladefoged, P. (1982). A Course in Phonetics. New York: Harcourt.

Lass, R. (1984). Phonology: An Introduction to Basic Concepts. Cambridge: CUP.

Le Page, R., \& Tabouret-Keller, A. (1985). Acts of Identity: Creole-Based Approaches to Language and Ethnicity. Cambridge: CUP.

Lefebvre, C., White, L., \& Jourdan, C. (2003). L2 Acquisition and Creole Genesis. Amesterdam: Benjamins. 
Lehman, W. (1962). Historical Linguistics: An Introduction. New York: Holt, Rinehart and Winston, Inc.

McLaughlin, B. (1987). Theories of Second Language Learning. London: Arnold.

Mitchell, T., \& El-Hassan, S. (1989). English Pronunciation for Arabic Speakers. London: Longman.

Moskowitz, A. (1970). The Two-Year-Old Stage in the Acquisition of English Phonology. Language, 46, 426-441. http://dx.doi.org/10.1093/applin/10.4.367

Mousa, A. (1994). The Interphonology of Saudi Learners of English (Unpublished doctoral dissertation). University of Essex.

Odlin, T. (1989). Language Transfer: Cross-linguistic Influence in Language Learning. Cambridge: CUP. http://dx.doi.org/10.1017/CBO9781139524537

Patrick-Ander, M. (2006). Second Language Acquisition and Creolization: Same (i-) Processes, Different (e-) Results. Journal of Pidgin and Creole Languages, 21, 231-274. http://dx.doi.org/10.1075/jpcl.21.2.01mat

Rickford, J. (1999). African American English: Features, Evolution, Educational Implications. Maiden, MA: Newbury.

Roach, P. (2000). English Phonetics and Phonology. Cambridge: CUP.

Schumann, J. (1978b). The Pidginization Process: A Model for Second Language Acquisition. Rowley MA: Newbury House.

Shumann, J., \& Stauble, A. (1983). A Discussion of Second Language Acquisition and Decreolization. In R, Anderson (Ed.), Pidginization and Creolization and Language Acquisition. Rowley, MA: Newbury House.

Verma, M., Firth, S., \& Corrigan, K. (1992). The Developing Phonological System of Panjabi/Urdu Speaking Children Learning English as a Second Language in Britain. In A. James, \& J. Leather (Eds.), New Sounds, 92, 174-199. Amsterdam: University of Amsterdam.

Washabaugh, W. (1977). Constraining Variation in Decreolization. Language, 53(2), 329-352. http://dx.doi.org/10.1353/lan.1977.0013

Wells, J. C. (1973). Jamaican Pronunciation in London. Oxford: Basil Blackwell.

Wells, J. C. (1982). Accents of English Beyond the British Isles. Cambridge: CUP. http://dx.doi.org/10.1017/CBO9780511611766

Winitz, H. (1969). Articulatory Acquisition and Behaviour. New York: Appleton-Century-Crofts

Wode, H. (1980). Phonology in L2 Acquisition. In S. W. Felix (Ed.), Second Language Development: Trends and Issues (pp. 191-193). Tubingen: Gunter Narr.

\section{Notes}

Note 1. Spirantization (fricativization) is a Spanish phenomenon whereby the voiced stops $/ \mathrm{b}, \mathrm{d}, \mathrm{g} / \mathrm{become}[\beta, \delta$, Y] respectively intervocalically (c.f., Hyman, 1975).

Note 2. An acrolect variety of speech in Creole language refers to the variety that is closest to the European based language, whereas the mesolect refers to an intermediate stage between the European based language and the Broad Creole.

Note 3. It is noteworthy to draw the reader's attention that $/ \mathrm{v} /$ does exist in Arabic, but as an allophone of $/ \mathrm{f} /$ in a certain context. That is, before an alveolar nasal. For instance, in such words as /jan(v)faSIl/ "he gets excited", /jan(v)fatıq/ "he/it rips open", etc., /v/ sound is produced before its voiceless counterpart /f/.

\section{Copyrights}

Copyright for this article is retained by the author(s), with first publication rights granted to the journal.

This is an open-access article distributed under the terms and conditions of the Creative Commons Attribution license (http://creativecommons.org/licenses/by/3.0/). 